\title{
Problemas a Equacionar no Serviço de 'Alimentação dos Grandes Hospitais $\left.{ }^{1}{ }^{1}\right)$
}

\section{HUMBERTO BALLARINY}

(Diretor do Hospital S. Francisco de Assis)

$\mathrm{P}$

ARODIANDo Coldwater poderíamos também dizer que o Serviço de Alimentação Hospitalar assemelha-se a uma grande árvore que reconforta os que buscam a sua sombra, evita a erosão do organismo e nos moldes da função clorofiliana recupera os desgastes do catabolismo doentio. Asssim sendo, concluímos da importância e complexidade do S.A. (Serviço de Alimentação) de um Hospital importância esta que errôneamente não lhe é atribuída pelos planejadores, arquitetos, engenheiros, diretores e chefes de divisões hospitalares.

Analisemos alguns problemas do Serviço de Alimentação em relação ao doente e à administração:

\section{I - EM RELAÇÃO AO DOENTE}

O Serviço de Alimentação e o paciente internado - Sua majestade, o "Rei do Hospital", tão cedo vença a primeira fase aguda de sua moléstia e comece a desfrutar conscientemente a comunidade hospitalar, sua reação inicial é às vêzes de gratidão ao médico e à enfermagem que the dispensaram os cuidados profissionais mas, sempre de revolta ao ambiente externo, donde proveio a causa de seu sofrimento. Geralmente enfastiado, inapetente, porém, intimamente convicto de que se deva alimentar para o seu pronto restabelecimento descarrega tôda a sua revolta na dieta pouco atrativa que the foi prescrita pelo médico, o que finge ignorar, mas, no seu entender, oferecida pela Administração do hospital. Mais tarde, já convalescente, servindo-se da dieta geral, sem restrições, está desejoso de satisfazer os caprichos individuais do seu paladar, revoltando-se contra o cardápio do dia que, ao ser planejado para uma coletividade difìcilmente poderá atender à certas preferências individuais. Tanto no primeiro como no segundo caso, o doente terá razões a seu modo de ver, para reclamar da Administração o tratamento que está recebendo do Hospital. Ora é a comida que é intragável, ora está fria, ou então está estragada e conclui sempre que assim não pode ficar bom, pois não consegue se alimentar. O Hospital o está matando de fome. $\hat{E}$ nesses casos que

(1) Tese apresentada ac $10^{\circ}$ Congresso Nacional de Hospitais, realizado no Rio de Janeiro em junho de 1955 
a atuação educacional da dietista junto ao leito do doente se faz imprescindível. A queixa virá então contra a Administração do Hospital, e o Diretor sempre atribui o fracasso, sem analisar a sua causa, à chefia do S.A. Mas, infelizmente, a queixa quase sempre tem fundamento, pois mesmo sendo bem executada a culinária e a cocção, o alimento, devido às dificuldades oriundas da distribuição, chega mal apresentado e frio à cabeceira do doente.

O alimento geralmente sai da cozinha, na melhor das hipóteses, com uma hora de antecedência em relação a sua ingestão. Até que o mesmo chegue aos serviços (cozinha distante, demora de elevadores, etc.), as bandejas estejam abastecidas, e os diversos leitos sejam servidos, o alimento já foi aquecido e esfriado várias vêzes, acusando profundas alterações organoléticas e oferecendo aos olhos do paciente uma apresentação pouco agradável. Somados a estas causas o pessoal subalterno, copeiras e serventes, que arrumam os pratos, procedem sem técnica, e no momento de oferecerem os mesmos aos doentes não fazem com urbanidade. O doente inapetente, a comida fria e mal apresentada, um serviçal pouco delicado e muitas vêzes mal instruído em certas regras de higiene, constituem alguns dos problemas a serem resolvidos diàriamente pelo chefe do S.A. Aos serventes, copeiros, cozinheiros, despenseiros e demais funcionários do S.A. devem ser ministrados ensinamentos sôbre higiene corporal e vestuário, tais como:

a) o valor e a significação para êles mesmos e para os doentes a quem vão servir, do hábito de banharem-se diàriamente e lavarem a miude os cabelos;

b) porque escovar os dentes, usar roupa sempre limpa, manterem-se sempre penteados e banhados;

c) porque nunca devem deixar de lavar as mãos depois de usarem o banheiro, manusearem o lenço, dinheiro, sapatos, material de limpeza ou qualquer objeto de uso coletivo. Porque devem conservar as unhas limpas e curtas, lavando bem as mãos antes de tocarem nos alimentos;

d) usarem touca ou gôrro para evitar a queda de cabelo na comida;

e) não utilizarem alimentos que tenham estado em contacto com moscas, baratas, ratos ou outros animais, nem tampouco aproveitarem o que tenha caído no chão;

f) comunicarem, imediatamente, para o devido tratamento ou afastamento do serviço, qualquer ferimento infeccionado das mãos, dôres de garganta, cólicas intestinais, diarréia, febre, etc.

g) manusearem o menos possível os alimentos, as louças e os demais utensílios a serem usados pelo doente.

Não esqueçamos que os serviçais do S.A. não têm noção de como servir bem aos pacientes e muitas vêzes o tratamento pouco delicado a êles dispensado é simplesmente fruto da ignorância. Portanto, cabe às dietistas a tarefa de instruí-los a respeito, fiscalizando constantemente se os seus ensinamentos foram bem assimilados. Devem os copeiros aprender a trabalhar sem barulho, evitando os ruídos de pratos e utensílios, para não perturbar os doentes. É importante também instruí-los como arrumar uma bandeja e como serví-la ao comensal. 
O Serviço de Dietética e o doente externo - Com a moderna orientação da nutrologia, a dietética foi incorporada à ciência médica como um dos mais valiosos recursos terapêuticos, não obstante a alimentação defeituosa ser a essência, podemos dizer, de quase todos os fatôres etiológicos.

Sob êste prisma tanto como medicina preventiva como curativa a dietética é arma poderosa da qual o hospital moderno não pode prescindir.

Nos hospitais gerais dos centros populosos o número de atendimentos diários de doentes externos é muito maior do que a média do doente-dia.

Assim, no H.S.E., a média de freqüência dos ambulatórios é de 800 a 1.000 atendimentos diários, enquanto o índice de ocupação é de 75 a $80 \%$ ou sejam em média 520 doentes internados. Logo o H.S.E. não podia deixar de orientar o doente externo na execução e cumprimento dos regimens dietéticos prescritos pelos médicos assistentes.

Assim, nos ambulatórios de clínica médica, de Pediatria e brevemente no de clínica cirúrgica, a dietista está à disposição dos médicos para calcular a dieta, explicar o uso de equivalentes e orientar a técnica de sua confecção, de modo a aumentar as probabilidades de êxito do tratamento.

\section{II - O S. A. E A ADMINISTRAÇÃo DO HOSPITAL}

As dôres de cabeça do Diretor em relação ao Serviço de Alimentação podem ser atribuídas a duas causas:

a) queixa dos doentes e dos funcionários contra o serviço;

b) problemas de natureza econômica, verbas estouradas com os gastos de manutenção e renovação do equipamento do S.A.

\section{a) Queixa dos doentes e dos funcionários}

Quanto às queixas dos doentes já analisamos as causas no capítulo anterior. Sôbre as reclamações dos funcionários o fenômeno é surpreendente, se analisarmos o aspecto psicológico da questão. $\mathrm{Na}$ maioria dos casos o hospital urbano fornece a alimentação aos seus funcionários por uma questão de cortezia, ou sob o aspecto de assistência social ao servidor, pois o horário de trabalho da maioria dos serventuários não residentes no hospital não justifica tal medida. A desproporção numérica entre o número de refeições servidas aos funcionários e aos doentes de um grande hospital é alarmante. No Hospital dos Servidores do Estado, por exemplo, para um total de 180.774 refeições servidas no mês de março apenas 26.519 dietas foram a doentes internados. Ora, esta situação chega a inverter os dados do problema, reduzindo o serviço de assistência dietética ao doente a $1 / 9$ das atribuições do Serviço de Alimentação.

Como dizíamos é interessante assinalar o problema psicológico das reclamações dos funcionários, principalmente dos de categoria subalterna. $O$ cardápio quando organizado e servido dentro das regras da dietética, acarreta reclamações sôbre a miséria das porções. - "É para matar de fome", são as expressões usadas. Quando são feitas tentativas de quebrar a monotonia do cardápio, variando os tipos de proteínas animais, tentando variegar com a 
inclusão de verduras, o mesmo é refugado e as críticas depreciativas chegam aos ouvidos do Diretor levadas muitas vêzes pelos próprios médicos com hábitos alimentares defeituosos. Outro aspecto interessante é o desregramento no comer, ou seja nos casos do subalterno, como compensação de "deficit" nutritivo em que se encontra, ou seja no de condição social melhor pelo espírito de aproveitar ao máximo o ofertado, pois o preço é fixo. Êsses fatos trazem sérias dificuldades para o planejamento, pois as quantidades previstas devem ser sempre muito majoradas, do contrário surgirão as críticas da falta de comida. As sobras e resíduos nem sempre traduzem má aceitabilidade da preparação, mas sempre significam alto custo de per capita. Não devemos olvidar que êstes cardápios podem representar $80 \%$ das refeições servidas num hospital, cuja verba destinada à aquisição de gêneros é prevista apenas para atender aos $20 \%$ relativos aos doentes internados. Não podemos esquecer também que a lotação do pessoal do S.A. nunca prevê esta situação e na distribuição do exíguo número de funcionários de baixo nível técnico, mas remunerados, sempre está faltando alguém em algum setor, prejudicando o bom andamento dos trabalhos de rotina.

A falta ao serviço, os direitos sem deveres da nossa atual legislação trabalhista e o horário do trabalhador inadequado à natureza dos serviços domésticos do S.A. hospitalar, obrigam o trabalho em três turnos de serviço o que triplica o número de executantes de tarefas, que não se interrompem durante as 24 horas do dia. Outro fator que contribui para o exagerado número de funcionários é a falta de planejamento, a ausência de funcionalidade na planta baixa do hospital em relação às necessidades da dietética hospitalar. $\mathrm{O}$ arquitetto e o engenheiro desconhecem ou não valorizam os problemas de um serviço que atende a todo o hospital, que não pode sofrer interrupções e que traz os maiores e mais freqüentes problemas administrativos para um Diretor. Assim, se aquêles técnicos prevêem e instalam um equipamento razoável para a confecção, não equacionam satisfatòriamente o problema do armazenamento, e jamais se preocupam com o insolúvel problema da distribuição perfeita do alimento confeccionado. A deficiência de elevadores nos monoblocos, o intenso trânsito entre as enfermarias, copas parciais, refeitórios e a cozinha, transtornam a execução do melhor dos planejamentos. Assim, novos problemas de distribuição vão surgindo a cada momento.

A solução habitual é a múltipla descentralização do serviço, hipertrofiando as copas dos andares, transformando-as em pequenas cozinhas e até mesmo em outros completos e autônomos serviços de dietética médica, a fim de atender às necessidades específicas a cada serviço. Esta hipertrofia de funções da copa dos andares constitui também outra justificação para o inevitável número elevado de funcionários de um S.A. hospitalar. Êste elevado número aparentemente absurdo estabelece no espírito do Diretor o permanente desejo de fazer cortes de pessoal no Serviço de Dietética. - "Aquilo não anda bem porque tem grande demais, sem fazer nada; não poderíamos aliviar - "deficit" do hospital diminuindo o númerc de servidores do S. A.?". Se analisarmos bem, em parte vamos concluir que êstes funcionários gastam mais tempo em idas e vindas, ou esperando os elevadores, do que servindo os doentes. Mas se diminuirmos êste número então surgem os atrasos no horário das 
refeições dos doentes, a comida cada vez chega mais fria e mal apresentada, logo, mais queixas chovendo no Gabinete do Diretor.

Para exemplificar o exposto, no presente momento, em face da falta de planejamento prévio das rotinas do Serviço de Dietética do H.S.E., trabalham naquele serviço 327 funcionários. A confecção é primorosa mas a distribuição é falha. Os doentes internados nos andares mais próximos da cozinha e que possuem uma boa equipe de copeiros do andar faltam ao serviço, o que é frequientíssimo, os doentes se queixam da qualidade da comida, chegando alguns que já freqüentaram diversas clínicas afirmar que a comida não é a mesma para todos os andares. No mesmo dia para o mesmo cardápio, recebemos de alguns andares os mais rasgados elogios e ao contrário de outros, impiedosas e exaltadas reclamações.

\section{b) Problemas econômicos administrativos}

Dentro da distribuição das verbas de manutenção o S.A. deve represen$\operatorname{tar} 1 / 3$ do total daquela dotação orçamentária e nem sempre isto acontece. Segundo Ella Bock da Universidade de Chigaco a verba do S.A. deve ser distribuída da seguinte maneira: aquisição de gêneros - $60 \%$; Pessoal $30 \%$; Diversos - $10 \%$.

A previsão orçamentária do H.S.E. para 1955 é de Cr\$ 194.720.276,00. Logo, aplicando o cálculo acima referido a verba do Serviço de Alimentaçáo daquele nosocômio deveria ser de $\operatorname{Cr} \$ 64.930 .020,00$.

Os dados da coluna à direita correspondem ao que preconiza ElLA Bock. No entretanto, confrontando com a coluna à esquerda que representa a verba realmente destinada ao S.A. naquele orçamento podemos constatar o que afirmamos linhas atrás:

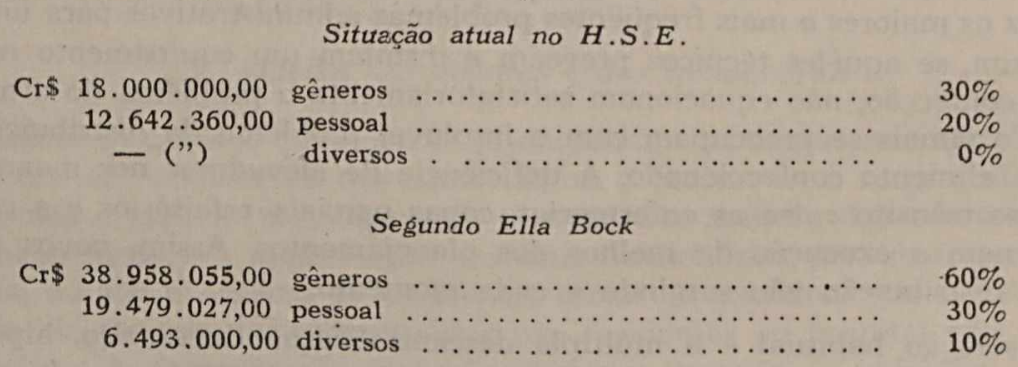

Não obstante o esclarecido tino administrativo da atual Direção do H.S.E., contornando a situação, não tem poupado esforços no sentido de reformar o equipamento e as instalações do Serviço de Dietética.

Já analisamos o angustiante problema do pessoal que pesa exageradamente no prato da balança onde são colocadas as despesas do hospital. A solução seria prever no planejamento da planta baixa uma circulação mais racional, entre a cozinha, as enfermarias e os refeitórios. No momento de equipar

(") Nenhuma dotação específica para renovação do material do S.A., apesar de que - prazo de utilização da maioria do material permanente instalado há 14 anos atrás já prescreveu. 
- hospital, não poupar verba na aquisição de uma completa aparelhagem mecânica para a culinária e a cocção para economizar a mão de obra numerosa em face do curto tempo disponível para execução daquelas tarefas.

Já pensaram o número de braços necessários para descascar, lavar e cortar, entre as 7 e as 9 horas da manhã algumas centenas de quilos de verduras, legumes e cereais? Sem a instalação de uma maquinária bem assistida tècn1camente, só com muito pessoal, pois os gêneros perecíveis só devem ser manipulados em cima da hora.

Muito nos impressionou numa visita que fizemos à cozinha do S.A.P.S. da Praça da Bandeira, onde vimos um verdadeiro formigueiro humano, cêrca de meia centena de mulheres aglomeradas em tôrno de uma mesa descascando uma pilha de sacos de batatas. Fomos informados de que um defeito na instalação elétrica havia paralisado repentinamente as máquinas e não nos lembramos quantas centenas de quilos de legumes já adquiridos deveriam ser preparados para o almôço. Meditem sôbre as dificuldades do Administrador para mobilizar aquela necessidade imprevisível de pessoal, pois o almôço não poderia deixar de ser feito e o desespêro do Diretor com o aumento da fôlha de pagamento.

Já que falamos na assistência técnica de manutenção da maquinária lembramos a necessidade de uma previsão orçamentária para fazer jus ao fabuloso desgaste em face do uso intensivo do equipamento usado pelo S.A. Como, via de regra, o problema não é equacionado, o serviço que vinha trabalhando em condições técnicas satisfatórias começa a decair e surge a necessidade de mais pessoal, pois o seu equipamento deixando de ser eficiente, obriga a admissão de mais funcionários. E, não obstante, a queda do padrão é uma conseqüência infalível. O funcionamento e a limpeza de tôdas as máquinas e pertences da cozinha dever ser exaustivamente explicado aos que vão ser responsabilizados pelos mesmos, a fiscalização da limpeza e conservação das geladeiras, das máquinas de lavar louça, das caldeiras a vapor (fogões, fornos etc.), deve constituir rotina diária da dietista encarregada do setor. Do contrário, o desgaste e a inutilização daquele material será rápida.

Faltando louça, talheres, legumeiras e os carros térmicos não funcionando acarretam aumento de pessoal para servir, lavar louça, transporte mais parcelado de alimentos, com maior demora no servir e, portanto, comida frita etc.

Outro ângulo do problema econômico diz respeito às despesas com a aquisição de gêneros alimentícios que estão sempre à desafiar e contrariar as previsões quer quantitativas, qualitativas ou econômicas.

Para o contrôle da quantidade de gêneros consumidos devemos pesar o cardápio fornecido para o setor e, posteriormente, o resíduo e sobras. Assim concluiremos pela má aceitabilidade do cardápio em função do resíduo, ou pelo êrro do planejamento quando a sobra fôr exagerada. A dietista deve vigiar bem a entrega do que desceu para o andar, pois, do contrário haverá facilidade de cortezias para com funcionários por parte das copeiras e assim as sobras desaparecerão e a verificação fica prejudicada.

E inacreditável a facilidade com que a formiga carregadeira aparece. Um pão com um pedaço de doce ou mesmo com um bife de permeio, um copo de 
leite, algumas frutas ou doces de sobremesa, levados pela mão dos bem alimentados comensais ao sairem do refeitório é coisa muito banal. E, no entretanto, as medidas coercitivas são sempre interpretadas como somiticaria da chefia do S.A., aumentando a gratuita animosidade contra tão vulnerável setor do hospital. A solução definitiva seria c pagamento da refeição proporcional aos alimentos consumidos, mas tal só seria viável com refeitórios adrede construídos para tal funcionamento.

Outro aspecto a considerar é o roubo de gêneros alimentícios entre a saída do aprovisionamento e o início da cocção. $\mathrm{O}$ alimento quando sai pesado do aprovisionamento mas não é acompanhado de perto durante o seu trânsito até entrar na panela ou ser consumido, constitui um dos falsos êrros atribuídos ao planejamento para explicar a falta de comida. Resultado: maior liberalidade do planejamento nas quantidades previstas e, portanto, aumento de despesas. O alcance dêsse desvio é imprevisível, pois o seu multiplicador está em função do número de empregados que manuseam os gêneros alimentícios, do vulto de gêneros manipulados diàriamente, da distância e das características do trajeto entre as fontes abastecedoras e consumidoras. Como exemplo podemos citar o resultado da aplicação dos mapas de contrôle que idealizamos para o H.S.E. (vide anexo "Mapa de Contrôle"). Assim, a carne recebida diàriamente pelo hospital era pesada e subia imediatamente para o frigorífico de onde, das grandes peças eram retiradas para as cozinhas os pêsos brutos a serem limpos esterilizados nas diversas preparações. No presente momento a carne é limpa no local da recepção por uma turma reduzida e controlado o pêso bruto, pêso líquido da carne limpa, pêso das aparas e pêso dos resíduos. O pêso dos resíduos é registrado como consumido pela preparação e para a cozinha sai do frigorífico apenas a carne limpa cujo pêso obrigatòriamente deve dar o rendimento exato previsto. Na limpeza da carne feita nas cozinhas pelos diversos elementos era fácil o roubo. Assim ficou provado pelo fato de que sem ter baixado o número de comensais, o planejamento começou a diminuir os pedidos de carne, pois o frigorífico estava sempre acusando sobras. Os dados estatísticos mensais acusaram o seguinte: no mês anterior ao contrôle o Hospital consumiu 11.489 quilos de carne, enquanto que no mês seguinte o consumo de carne baixou para 8.595 ou sejam, exatamente 2.894 ks. a menos. Dêste fato concluímos o vulto do trabalho da formiga carregadeira.

Outro exemplo frizante dos inconvenientes da falta de planejamento funcional das instalações do Serviço de Alimentação é o que daremos a seguir: na aplicação dos mapas de contrôle para o aprovisionamento de frutas não havia jeito de conferir o estoque existente assinalado no mapa, com a quantidade de frutas realmente existente no frigorífico. Estávamos para punir o responsável quando tivemos ocasião de surpreender inocentes descuidistas que se serviam das frutas depositadas nos caixotes a espera do elevador que deveria transportá-las em sucessivas viagens do andar térreo para o $110^{\circ}$ anđar onde estão localizados os frigoríficos. Assim, as uvas, as laranjas, as bananas, etc., recebidas do fornecedor e dadas como entradas no frigorífico numèricamente não conferiam. Solução: aumentar o número de funcionários da recepção, dividindo responsabilidades ou então desistir do contrôle. O importe do desvio era maior do que a despesa com o aumento de funcionários. Logo, 
achamos preferível enfrentar um não do Diretor com a proposta de mais funcionários. A repetição de inúmeras situações semelhantes justificam a nosso ver o atual número crescente de funcionários de Serviço de Dietética do H.S.E. O problema da qualidade dos gêneros fornecidos a um hospital é transcendental, pois não só o seu aspecto físico interessa, mas principalmente o seu estado higiênico de conservação. A fonte de origem deve ser conhecida e merecer tôda a confiança, pois, não se concebe que doenças transmissíveis pelos alimentos possam ser acrescidas aos sofrimentos que trouxeram o doente ao hospital. Neste particular fazemos um apêlo às escolas formadoras de dietistas no sentido de ampliar os ensinamentos necessários ao reconhecimento das diversas qualidades de um mesmo gênero alimentício e ao julgamento sôbre o estado higiênico dos mesmos, de modo a refugar, após rigoroso exame, o material inadequado às exigências impostas pela natureza do consumidor.

Comprar os alimentos par bom prêço é problema assás difícil em hospitais de grande consumo, mormente nos oficiais, pois o absoleto Código de Contabilidade e a atual forma de concorrência pública não se coadunam às características do mercado de gêneros alimentícios. A variabilidade de preços que o mesmo mercado iria apresentar leva o fornecedor concorrente a majorar sempre os preços vigentes no sentido de não ter prejuízo no caso de uma alta. O desaparecimento de determinado gênero tabelado como medida aitista geralmente deixa de ser fornecido com a desculpa de não existir na praça. Assim, a experiência demonstrou que as coletas de preço devem ser mensais, a fim de não ficar o hospital prêso a um fornecedor fixo e ter os seus preços sempre atualizados, facilitando desta maneira a entrega daquilo que foi planejado e não a alteração de última hora do cardápio programado.

Os carcápics devem ser planejados no mínimo com um mês de antecedência e as quantidades dos gêneros necessárias serão totalizadas dentro de uma estimativa ligeiramente majorada, que constituirá o edital de concorrência para a coleta de preços mensal já referida anteriormente.

Pelo que temos observado e pela bibliografia consultada concluímos ser a distribuição de alimentos um problema ainda sem solução satisfatória para os grandes hospitais.

O sistema descentralizado de distribuição ou Bulk-Service dos americanos é usado na maioria de nossos hospitais. Consiste em enviar os alimentos em diversos vasilhames ou carros tanques para as copas dos andares onde são feitos os pratos, legumeiras ou arrumadas as bandejas individuais para a posterior distribuição aos doentes. Cartões nominais, cêrca de 700 , com o tipo de dieta ( $\mathrm{n}^{\circ}$ do leito) são preenchidos diàriamente para individualizar as bandejas. Troca de cartões são acidentes muito comuns naquela azáfama de distribuir as bandejas pelas enfermarias. O tempo que a comida leva depois de pronta para chegar ao andar, somado aos minutos gastos em servir as legumeiras e os pratos, acrescido de resfriamento pela manipulação da panela para o recipiente do andar, e daqueles recipientes para um prato frio, são razões suficientes para alterações organoléticas que só aumentarão a repulsa por parte do doente inapetente.

Sob o ponto de vista econômico as copas parciais com a autonomia que lhes confere o Bulk- Service, facilitando como já assinalamos à formiga car- 
regadeira, são ante-econômicos. No H.S.E., por exemplo, cêrca de 12 copas parciais eram abastecidas diàriamente com açúcar, frutas, doces em pasta, queijos etc., enfim uma lista enorme de especiarias que na maior parte das vêzes não chegavam ao doente. O outro sistema conhecido é o centralizado ou central-tray, onde os pratos de cada paciente são feitos na própria cozinha e levados aos doentes sem a passagem pelas copas dos andares. São necessárias amplas instalações de balcões térmicos distribuidores, numerosos carros de transporte, elevadores e monta-cargas à disposição exclusiva do S.A., para evitar o resfriamento. A indústria americana já possui o sistema mealpark onde recipientes de pirex são aquecidos por lâmpadas infra-vermelha, abastecidos de comida através de esteiras rolantes, e fechados em recipientes de metal pelo sistema de vácuo. Assim, conservam por algumas horas em perfeito estado as condições organoléticas do alimento. E' uma instalação dispendiosa e deve ser prevista na planta de construção. O sistema é bem mais racional e econômico sob o ponto de vista de desvios de comida, mas apresenta um sério inconveniente: não permite atender às preferências pessoais dos doentes, às vêzes bem conhecidas pelos copeiros do andar. No H.S.E. estamos, no momento, estudando a possibilidade de criar uma copa geral que centralize tôda a distribuição para os andares, das seis refeições diárias: Desjejum - Colação - Almôço - Merenda - Jantar - Ceia.

A terceira e quarta dietas desceriam da cozinha geral, diretamente para os andares no carro térmico, e os pratos seriam confeccionados a gôsto do doente diretamente na cabeceira do seu próprio leito.

Quanto aos regimens especiais hipocloretados, hipograxos, para diabéticos, de segunda e de primeira etc., seriam servidas as legumeiras na cozinha dietética pela própria copeira mais identificada com os doentes do andar e transportados diretamente para as enfermarias sem passar pela copa. Para evitar os cartões identificadores foram organizados mapas de distribuição onde figuram o número do leito e o tipo de cardápio para no máximo 30 pacientes, número atribuído à responsabilidade de um copeiro.

Procuramos também um sistema de diferenciação das legumeiras, de modo que um determịnado número ou côr identifique o tipo de dieta contido na legumeira, facilitando a sua entrega ao enderêço certo.

Outro problema administrativo que surge em relação ao Serviço Dietético é a falta de um perfeito entrozamento com o Serviço de Enfermagem. Convém definir as atribuições da dietista e da enfermeira, do contrário quem sofre é o doente.

A nosso ver cabe ao S.A. a tarefa de transformar a indicação dietética prescrita pelo médico assistente no regimem alimentar do doente. Uma vez manipulada a receita é a mesma entregue ao Serviço de Enfermagem pelos serviçais do S.A. no leito do doente, ou na copa parcial. A administração dos alimentos ao doente com inapetência funcional, ou alimentado por sonda é tarefa do Serviço de Enfermagem e não do Serviço de Alimentação.

Quando a aceitação não fôr boa, ou c doente não tolerou bem a medicação ou a alimentação, cabe à enfermeira comunicar ao médico, e informar à dietista o ocorrido para as devidas providências. As modificações de dietas feitas pelo facultativo durante a visita diária, obrigatòriamente assistida pela 
enfermeira responsável pelo leito bem como os casos de alta e transferência, devem ser comunicados pela mesma à dietista. Caso contrário, a dietista ficaria obrigada a folhear tôdas as papeletas, violando o segrêdo profissional e perdendo um tempo precioso para se inteirar daquelas modificações. $\mathrm{O}$ problema pode ser simplificado pelo preenchimento, por parte da enfermeira, da ficha que adotamos no H.S.E.

Como puderam ver pelo relato feito os problemas do S.A., do H.S.E. se identificam com os de todos os grandes hospitais. Todo serviço deve ter um regimento interno que defina atribuições e fixe responsabilidades pois, do contrário, não terá estima administrativa. A centralização exagerada da chefia executiva nos grandes serviços é coisa do passado, pois a concepção moderna é do coordenador de equipe e não do onipresente e onisapiente chefe de serviço.

Pensando desta maneira e levando em conta os problemas discutidos linhas atrás apresentamos a seguir um modêlo de Regimento Interno de um Serviço de Alimentação, aplicável em hospitais gerais de mais de 700 leitos (vide em anexo).

MODELO DE UM REGIMENTO INTERNO PARA O SERVIÇO DE ALIMENTAÇÃO DE UM HOSPITAL GERAL DE 700 LEITOS

\section{I - DAS FINALIDADES E ORGANIZACÃo}

Art. $10^{\circ}$ Ao S.A. (Serviço de Alimentação) compete:

I - Prestar assistência alimentar aos doentes internados e seus acompanhantes, aos funcionários e demais pessoas que a Administração julgar de direito, controlando técnica e econômicamente a alimentação geral do Hospital, bem como orientar o doente externo na execução e cumprimento dos regimens dietéticos prescritos pelo médico assistente.

II - Colaborar com os diversos serviços do Hospital através de:

a) análise, preparação e distribuição de regimens dietéticos especiais;

b) contrôle perfeito da eficiência dos regimens e dietas prescritos;

c) estudos sôbre nutrição;

d) educação alimentar através de conferências e outros meios de divulgação dos modernos conhecimentos sôbre a ciência da nutrição;

e) receber da Divisão de Administração a mais estrita colaboração no sentido da maior eficiência e rapidez na distribuição da alimentação aos doentes;

f) orientar o Serviço de Compras na aquisição dos gêneros alimentícios e o equipamento especializado requisitados, quanto à sua qualidade e estado de conservação dos mesmos;

g) fornecer à Contabilidade os elementos necessários à elaboração da proposta orçamentária e a escrituração contábil das indenizações de material ou despesas extraordinárias com a alimentação atribuídas a pacientes internados ou demais pessoas que freqüentem o Hospital.

"Considera-se como despesa extraordináría com a alimentação todo alimento servido fora das cinco refeições diárias: Desjejum - Almôço - Merenda Jantar e Ceia, salvo os regimens dietéticos especiais prescritos pelo médico assistente."

Art, 2. ${ }^{\circ}$ O S.M.D. chefiado de preferência por médico nutrólogo, compõe-se de:

I - Seção de Planejamento

II - Seção de Cozinha 
III - Seção de Copa Geral e Distribuição

IV - Setor de Pediatria

$\mathrm{V}$ - Setor Administrativo

VI - Setor de Estudos e Pesquisas.

Art. 3. ${ }^{\circ}$ À Seção de Planejamento, constituída de três setores: aprovisionamento, dà clínicas e contrôle técnico, compete:

a) enviar ao S.A.M. ou às fontes abastecedoras credenciadas por êle, com a devida antecedência, a previsão dos gêneros alimentícios a serem consumidos pelo Hospital, fiscalizando no ato da aquisição a qualidade dos mesmos e devolvendo os que não estiverem em condições satisfatórias;

b) responsabilizar-se pela conservação dos gênerós até o momento da entrega à cozinha;

c) colher junto aos doentes os dados técnicos e pessoais necessários ao planejamento das dietas e regimens especiais prescritos pelos médicos;

d) totalizar o número sintetizzr as dietas gerais e os regimens especiais de todo o hospital;

e) elaborar, de acôrdo com o aprovisionamento, a síntese dos diversos cardápios a serem confeccionados pela seção de cozinha, observando rigorosamente a técnica, sem desprezar o fator econômico;

f) controlar tècnicamente o equilíbrio das rações realmente consumidas e analisar êrros de planejamento ou de cocção, fornecendo os elementos necessários a suas correções.

Art. $4 .^{\circ}$ A seção de Planejamento será chefiada por uma dietista auxiliada por outra e três encarregadas de setores.

Art. 5. ${ }^{\circ}$ A encarregada do setor Aprovisionamento seria responsável pelo pessoal da despensa e do frigorífico, pela qualidade e estado de conservação dos alimentos.

Art. $6 .^{\circ} \AA$ A encarregada do Setor das Clínicas que supervisiona o grupo de dietistas dos àndares compete fiscalizar e totalizar os pedidos de dietas de todos os andares.

Art. $7 .^{\circ}$ As dietistas dos andares compete:

a) conhecer os alimentos sob c ponto de vista químico, fisiológico, higiênico e econômico;

b) conhecer por experiência própria como preparar as diversas dietas no Hospital;

c) prever, organizar, coordenar e controlar as atividades do setor sob sua responsabilidade;

d) zelar pelo fator econômico, quer planejando, quer fiscalizando os desperdícios, quer recuperando as sobras;

e) aproveitar tôdas as oportunidades para transmitir aos doentes os modernos conhecimentos sôbre alimentação, de modo a colaborar na recuperação orgânica dos mesmos ou na prevenção das doenças metabólicas provenientes de mạus hábitos alimentares;

f) instruir os funcionários subalternos de modo que os mesmos possam servir os doentes com higiene, técnica e urbanidade.

Art. $89^{\circ}$ A encarregada do setor Contrôle Técnico acumularia os encargos do setor de Estudos e Pesquisas.

Art. 9. À seção Cozinha constituída da Preparação, Cozinha Geral e Cozinha Dietética, compete tôda a manipulação dos gêneros alimentícios compreendidos entre a culinária e a cocção até o momento da sua entrega à copa geral para a distribuição. tistas.

Art. 10. A seção Cozinha será chefiada por uma dietista, auxiliada por duas die-

Art. 11. À seção Copa Geral, constituída do setor de Distribuição Geral, Confeitaria e Copa de Plantão, compete:

a) distribuir todos os alimentos às diversas dependências do hospital;

b) preparar o desjejum, a merenda, a ceia dos funcionários do plantão noturno, os sucos de frutas, as sobremesas e os pedidos extraordinários a qualquer hora;

c) lavar a louça, remover o livro e manter em perfeita limpeza todos os setores: sob a sua responsabilidade. 
Art. 12. A seção Copa Geral seria chefiada por uma dietista auxiliada por duas encarregadas dos setores de distribuição geral e confeitaria e duas plantonistas para atender o funcionamento dia e noite da copa de plantão.

Art. 13. Ao setor de Pediatria compete o planejamento, confecção e distribuição da dietética infantil.

Art. 14. O setor de Pediatria, em face das suas características: cozinha própria, sistema de distribuição etc.., tem rotina diferente da do setor de Clínicas. Assim será chefiada por uma dietista encarregada de setor.

Art. 15. Ao Setor de Administração ligado diretamente ao Gabinete do Chefe do S.M.D. compete solucionar os problemas administrativos, relacionados ao pessoal, material, contabilidade, documentação e estatística, de todo o serviço.

Art. 16. Ao Setor de Estudos e pesquisas compete promover cursos de aperfeicoamento para o pessoal subalterno e reuniões periódicas entre o "staf" técnico, divulgar as observações técnicas do S.M.D. e incentivar a reılização de pesquisas sôbre alimentação.

Art. 17. Êste Setor de Estudos e Pesquisas terá como responsável a dietista encarregada do contrôle técnico da seção de Planejamento orientada pelo médico nutrólogo.

\section{CONCLUSÕES}

$1^{\circ}$ ) O planejamento do Serviço de Alimentação hospitalar deve começár com os primeiros projetos do arquiteto;

2..$^{\circ}$ O Serviço de Alimentação hospitalar desempenhando papel preponderante na recuperação psicossomática dos doentes deve estar subordinado à Divisão Médica;

3. ${ }^{\circ}$ Cabe ao médico nutrólogo dirigir o Serviço de Alimentação dos grandes hospitais gerais.

$\left.4^{\circ}{ }^{\circ}\right)$ Os serviços técnicos do Serviço de Alimentação devem ser desempenhados por especializados como medida de segurança para os doentes e de economia para a Administraçãc do hospital;

$\left.5 .^{\circ}\right)$ Verbas insuficientes empregadas nas instalações redundam em manuntenção pouco econômica;

$6^{\circ}$ ) O sistema de distribuição centralizádo com instalações adequadas é o que apresenta melhor rendimento;

7..$^{\circ}$ Um contrôle geral prático e rigoroso é imprescindível à eficiência técnica e econômica do Serviço de Alimentaçãc do hospital. 


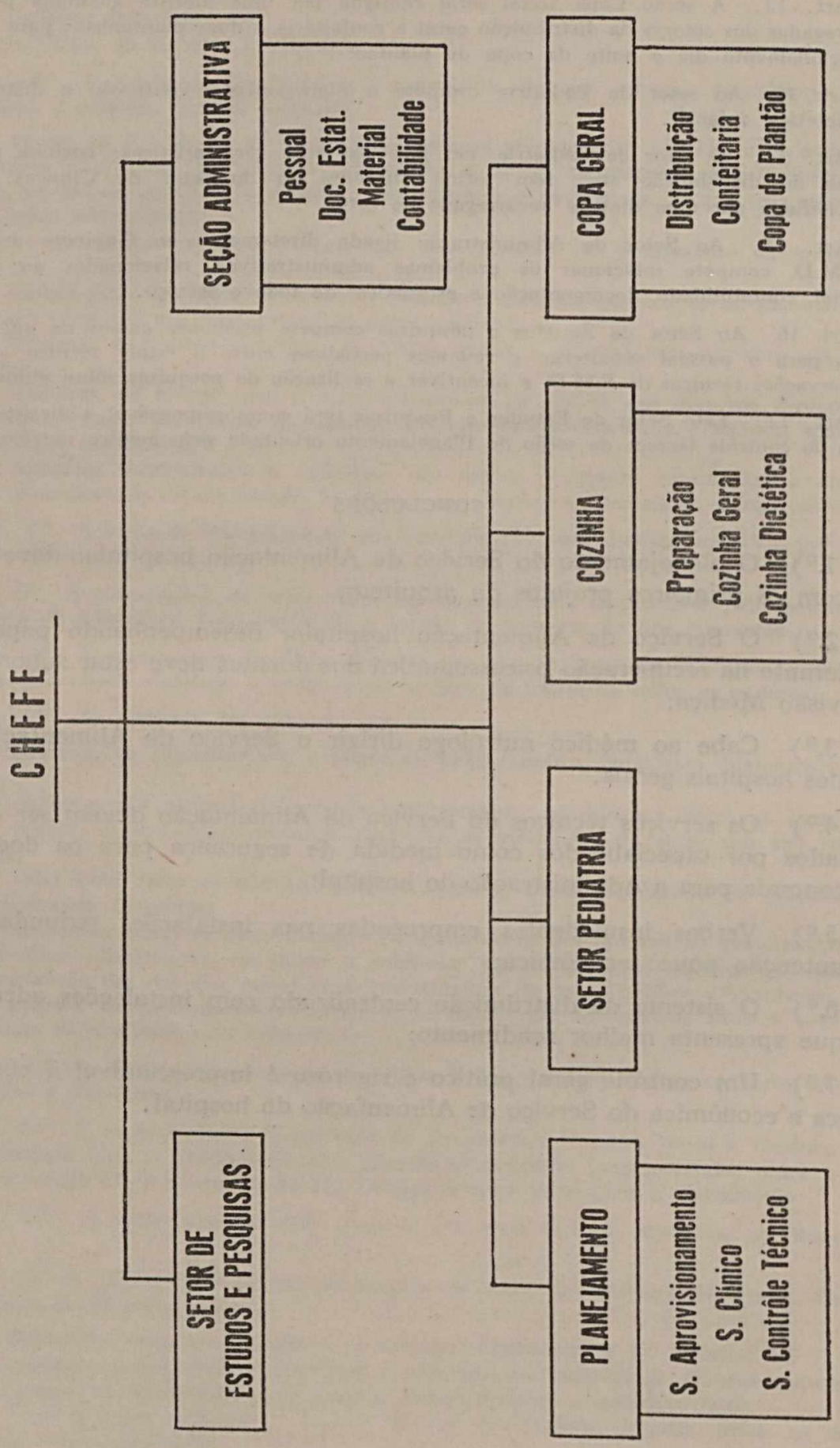

